\title{
SEED TECHNOLOGY TRAINING IN THE YEAR 2000
}

\author{
M.B. MCDONALD ${ }^{1}$; J. MARCOS-FILHO ${ }^{2,4}$; R.J. BINO ${ }^{3}$ \\ ${ }^{1}$ Dept. of Horticulture and Crop Science, The Ohio State University, Columbus, OH 43210-1086 USA. \\ ${ }^{2}$ Depto. de Agricultura-ESALQ/USP, C.P. 9, CEP: 13418-900 - Piracicaba, SP, Brasil. \\ ${ }^{3}$ Centre for Plant Breeding and Reproduction Research, P.O. Box 16, 6700 AA Wageningen, The Netherlands. \\ ${ }^{4}$ Bolsista do $\mathrm{CNPq}$
}

\begin{abstract}
Seed quality will remain the centerpiece of successful agricultural programs in the year 2000. As new changes occur in agriculture driven by advancements in biotechnology, seed enhancement technologies, a more diverse seed user clientele, and communication technologies, successful seed companies will require a knowledgeable and informed workforce to assure high seed quality. A new approach to seed technology training is professed that relies on the establishment of a three-institution consortium to achieve this objective. Advantages of the consortium are identified that emphasize the unique strengths of each institution, their geographic advantages representing major climactic/ agricultural zones in the world, and differing approaches to seed technology training that are facilitated by increasing ease of global communication. This may be a better way to conduct seed technology training in the year 2000 .
\end{abstract}

Key Words: seed quality, education, seed industry, biotechnology, seed enhancements, consortium

\section{TREINAMENTO EM TECNOLOGIA DE SEMENTES NO ANO 2000}

RESUMO: A qualidade das sementes deverá permanecer como centro das atenções em programas avançados de produção agrícola no próximo milênio. À medida que novas alterações ocorrem na agricultura, como decorrência de avanços da biotecnologia, da tecnologia para aprimorar o desempenho das sementes, da diversidade de exigências dos consumidores e da evolução de tecnologia de comunicação, as empresas de sementes deverão exigir profissionais mais competentes e bem informados para produzir sementes de alta qualidade. Para atingir esse objetivo, uma nova abordagem para o treinamento em tecnologia de sementes é apresentada neste trabalho, baseada no estabelecimento de um consórcio entre três instituições de ensino e pesquisa. São, também, identificadas vantagens do consórcio, enfatizando-se os pontos fortes específicos de cada instituição, as vantagens de sua localização geográfica, representando regiões das mais importantes dos pontos de vista climático e agrícola, com abordagens distintas para o treinamento em tecnologia de sementes, que são facilitadas pelo avanços da comunicação global. Essa pode ser a melhor maneira de conduzir o treinamento em tecnologia de sementes nos anos 2000. Descritores: sementes, qualidade, educação, programas de sementes, biotecnologia, desempenho, consórcio

\section{INTRODUCTION}

Seed technology training in the year 2000 what will it be like? Will society continue to maintain the present academic structure of educating students in seed biology at universities so they become successful employees of vibrant seed industries? Will research programs in seed science and technology be sufficiently comprehensive and contemporary so the seed industry is able to rapidly adapt to the demands of a more sophisticated consumer? How will the increasing international trade of seed be accomplished in view of phytosanitary and other legal requirements?
Will the value of seed be of more or less importance to the farmer? Will farmers remain the principal users of seed or will agriculture become more specialized as value-added components are introduced into the seed?

No one, of course, can answer these questions, but they need to be asked. What is certain is that there is no coordinated effort to determine how the seed industry and its employees will be educated and best serve society by the year 2000 . The needs remain the same. Successful agriculture will depend on high quality seeds. Further, while developed countries in North America and Europe have excellent seed industries, the same is not true for the rest of the

Sci. agric., Piracicaba, 55(Número Especial), p.1-5, agosto 1998 
world. But, seed is now recognized as an international commodity. Most major seed companies have forged recent alliances with important chemical companies that possess successful biotechnology programs. Examples include Pioneer/DuPont, Monsanto, Novartis, Mycogen, etc. These international conglomerates will require the successful operation of seed companies in every part of the world. This means they need a knowledgeable staff capable of producing a quality product and sufficiently competent to solve local problems. Where will these individuals come from and who will be the seed technology decision-makers in the year 2000 ?

\section{HISTORY OF SEED TECHNOLOGY TRAINING}

While many academic institutions have assisted the development of seed technology training, few institutions have had greater impact during the last 30 years than Mississippi State University. This single university brought together a competent academic staff addressing specific seed technology issues, provided outstanding research and teaching facilities, and maintained a long-standing commitment to upgrading the global knowledge about the production of quality seeds from the laboratory to the field. The economic impact that this university had worldwide in improving global agriculture through the use of quality seed and educating an era of knowledgeable seed technologists is a model to emulate.

As times have changed and individuals retire, the focus of seed technology at Mississippi State has likewise been altered. Gone, and not replaced, is that competent staff. Who now do we turn to for expertise? Maybe, some would suggest it's not important. Others might argue that the seed industry can now best train those individuals vested in the seed business. Maybe, all that we need to know about high quality seed production is known. However, the purpose of this discussion is to suggest that none of these solutions are appropriate. Change is rapidly occurring in agriculture and presents new and exciting opportunities. What remains as critical as before, however, is that seed quality will remain the centerpiece of successful agriculture.

What's driving change? Changes are rapidly occurring in agriculture, many of these at the level of the seed industry. There are at least four factors driving this change that ultimately will culminate in improved and more valuable seed products.
Biotechnology: Without question, biotechnology will have a major impact on the seed industry and seed technology. There presently are three principal foci of biotechnology research. These include: 1) seeds with "input traits" (insect resistance, herbicide resistance, disease resistance, increased yield, etc.). Ultimately, these new products will cause a shift in farmer spending from the agricultural chemical industry where pesticides and chemicals were formerly provided to the emerging seed/agricultural biotechnology industry, 2) seeds with "output traits" (healthier oil content, improved nutritional value, etc.). These products will open new venture opportunities in food and feed markets not available before, and 3) new biotechnology products will eventually extend into pharmaceutical, neutraceutical, and industrial applications (oils, polyesters, etc.). Such products will touch every aspect of a person's normal life.

Who will be the beneficiaries of these products and what does it all mean to seed technology? The beneficiaries include farmers who will obtain higher crop yields from improved insect, weed, and disease control. Because these controls are obtained without chemical use, less concern will exist about environmental pollution. Farmers will also benefit from lower input costs for pest/weed control and will likely obtain price premiums for grains with selective output traits. Seed companies such as Pioneer, DeKalb, Novartis, etc. will also benefit from increased biotechnology seed premiums that will increase seed margins. Those companies that are the research and development leaders will likely enjoy a market share advantage from being the first to offer their new products. Finally, gene providers such as Monsanto, DuPont, Dow, etc. will obtain additional income from per acre gene fees and, in some cases, increased herbicide market share for companies selling herbicideresistant seeds.

Is this really going to happen? TABLE 1 illustrates that genetically modified corn and soybean seeds are expected to be on five times the acreage for corn and four times the acreage for soybean in the United States by 2001 . This will have an impact. It has been estimated that the worldwide 1998 value of seed is $\$ 15$ billion. By 2005, this value will increase 33\% to $\$ 20$ billion (Furman Selz, 1998). Recognizing the importance of these new markets and genetically modified products, seed technology will necessarily be at the front of ensuring the quality of these new 
biotechnology products. Moreover, the increasing value of seeds in the future portends that high quality seeds will be paramount to avoid litigation concerning poor performance.

TABLE 1 - Total United States seed industry acreage in genetically modified corn and soybean seeds from 1997 to 2001 .

\begin{tabular}{lrrrrr}
\hline Product & 1997 & 1998 & 1999 & 2000 & 2001 \\
\cline { 2 - 6 } & & & & \\
\cline { 2 - 6 } Corn & 4 & 12 & 18 & 24 & 30 \\
Bt & 3 & 1 & 3 & 5 & 10 \\
Roundup ready & 1 & 4 & 5 & 6 & 6 \\
Other herb. resist. & 1 & 1 & 2 & 3 & 4 \\
High oil & 0 & 18 & 28 & 38 & 50 \\
TOTAL & 8 & 18 & & & \\
Soybean & & & & 31 & 33 \\
Roundup ready & 8 & 24 & 28 & 6 & 6 \\
Other herb. resist. & 4 & 5 & 5 & 6 & 39 \\
TOTAL & 12 & 29 & 33 & 37 &
\end{tabular}

Improved seed enhancement technologies: our understanding of the factors that govern desiccation tolerance and the activation of seed germination during the earliest stages of imbibition will lead to improved seed enhancement technologies applied to a greater diversity of crop species. Most seed companies apply enhancements only to their highest vigor seeds, so new technologies to monitor seed vigor, such as computer imaging, may prove valuable. It is also known that enhanced seed stores poorly and proper inventory management will be critical for successful application of enhancements in the future.

Farmers aren't the only users of seed: while farmers will continue to be the prime beneficiary of seed improvements, there will be an increasing demand for better quality seeds from vegetable and flower transplant growers. Transplants assure rapid growth and uniform spacing of the crop in the field or greenhouse and the increasing reliance on transplants has spurred the establishment of a new bedding plant industry that germinates seeds in plug flats. These are subsequently marketed for transplant to bedding plant and greenhouse industries. Plug production, however, has created important requirements for high quality seeds that include: 1) each seed placed in a plug cell must germinate. To do otherwise results in unfilled plugs, inefficient use of greenhouse space, and the need to refill empty cells - a costly, time consuming operation, 2) all seeds planted in a plug tray must germinate rapidly and uniformly. Rapid emergence is essential for faster greenhouse turnaround and frees up more greenhouse space for additional plants. Uniform emergence permits more accurate timing of shipments and creates a more desirable tray appearance to the buyer. Today's vegetable and flower marketplace demands $100 \%$ filled cells in a plug tray and plug growers are willing to pay increased seed costs associated with higher seed quality.

The globe is smaller: too often, programs are constrained by state and national boundaries. Recent seed industry mergers reveal that these artificial walls will no longer be acceptable in an increasingly dependent global market economy. What will reduce the size of the globe even more dramatically is the rapidly evolving communication revolution. This begins with the decreased costs and ease associated with global travel. Individuals can now travel to differing countries and have meaningful interchanges previously considered difficult to accomplish. But, more important is the ability to exchange concepts and discourse anywhere in the world at a moment's notice by electronic mail instead of "snail" mail that previously required days or weeks. Visiting World Wide Web sites also provides easily accessible data bases formerly requiring weeks/months to assemble. Untapped yet is the vast resource of long-distance learning where classrooms will be conducted anywhere in the world for the benefit of future students. These changes have reduced the distance needed for immediate communication and exchange of ideas, facilitating better learning and research.

\section{A NEW WAY TO CONDUCT SEED TECHNOLOGY TRAINING: A CONSORTIUM}

The case has been made that seed quality will continue to be an important agricultural concern. The seed industry, therefore, must assure that active research programs exist around the world and that there is a steady provision of trained and educated seed technologists to monitor seed quality. Historically, international funding agencies concerned about agricultural development, such as USAID and the World Bank, have relied on the comprehensive seed technology expertise of one institution as illustrated by Mississippi State University. We now argue that this historical process is limiting and that recent developments in communication present a new way to conduct seed technology training. As an 
example, three institutions (The Ohio State University - OSU, Escola Superior Agricultura "Luiz de Queiroz - ESALQ," and Centre for Plant Breeding and Production Research - CPRO-DLO) with successful histories in seed technology have forged a Consortium for International Training in Seed Technology (CITST) to provide comprehensive training in seed technology. The following represents the strengths of CITST.

Comprehensive/Deep: It is a comprehensive program. Thirty eight (38) faculty with interests in seeds are participants. Expertise includes seed production, seed pathology, seed processing, seed testing, and seed physiology/biochemistry to seed policies, biodiversity, and on-farm conservation strategies. Crops covered range from orthodox and recalcitrant agronomic, vegetable, flower, turf, woody/ herbaceous, tropical forages to weeds. It is a deep program. CITST partners consider every aspect of seed production ranging from important issues such as seed conservation, use of agro-biodiversity, seed technology, variety testing, seed legislation to seed policies and management. CPRO-DLO includes a "participatory base" program where seed expertise is directed towards specific training requests focused to local problems.

Geographic location: each academic institution was selected because of its geographic location. Ohio State is located in the US corn belt and has active vegetable and flower seed production. ESALQ is in Brazil where excellent agronomic seed production exists in the South while the North and Northeastern regions continue to develop from a seed production perspective. CPRO-DLO has a close association with the high value vegetable and flower seed industries in Europe, thereby providing an important and differing seed technology perspective. Because of the location of CITST on three continents, anyone interested in seed technology expertise can readily access it.

Facilities: State-of-the-art research and training facilities for seed technology are present at each CITST institution. OSU is noted for its seed physiology and seed production capability. ESALQ possesses a model on-site seed processing plant. CPRO-DLO is a leader in the application of computer capability for seed technology as well as pioneering seed enhancement research.

Seed technology capability: each CITST institution has experience in education and training of seed technologists. Regular seed technology workshops are offered. Moreover, because CITST partners are affiliated with major land-grant institutions, they draw on a vast array of agricultural expertise to provide unique and in-depth seed technology training. Important issues such as small business development, seed quality control/ISO quality assurance systems, and seed and variety legislation in developing countries can be addressed.

International experience: CITST members have recognized international relationships and consider these important components of their training programs. Faculty in the OSU Seed Biology Program have collaborated with or participated in seed development projects in such countries as China, India, Argentina, Brazil, Dominican Republic, Egypt, Sudan, South Africa, Colombia, Mexico, Uganda, and Poland. CPRO-DLO has been active in seed projects in Indonesia, Kenya, Brazil, Bangladesh, China, Philippines, Burma, Sri Lanka, and Syria.

Established seed industry/Association relationships: CITST has excellent working relationships with local seed industries. These permit candidate training that represents an integrated continuum from the principles of seed technology learned in the laboratory to the practices of seed production accomplished on the farm or within the company. In addition, it is possible to establish internships with private seed companies where trainees actually participate in seed production onsite. If necessary, it is also possible that specific types of seed technology training can be provided by the seed industry in conjunction with the overall training program. Each CITST member also actively participates in seed associations such as the International Seed Testing Association (ISTA), Association of Official Seed Analysts (AOSA), Union for Plant Variety Protection (UPOV) and others ensuring that competence exists for activities associated with seed testing at the international level.

\section{ADVANTAGES OF CITST}

The Consortium draws on the unique strengths of each institution, their geographic advantages representing major climatic/agricultural zones in the world, and differing approaches to seed technology training. Seed technology training includes short-term Workshops as well as long-term educational training at the Masters/Ph.D. level, when 
needed. The primary training would be at one institution with secondary training at the other institutions so that students/participants gain additional insights and differing cultural/technical experiences. Training within seed companies, either short-term or as interns, is encouraged. In-country training by faculty from the three institutions as consultants would be expected.

The establishment of CITST is a novel approach to global training in seed technology. To continue seed technology training as we have in the past with single institutions ignores the rapid advances in communication as new computer and interactive technologies decrease the size of the world. It also fails to take advantage of the vast expertise of several institutions that differ globally and environmentally.
This Symposium and Special Seed Biology Publication represent an illustration of the diversity of seed technology topics and the breadth of expertise that such a Consortium musters. This may be a better way to conduct seed technology training in the year 2000.

\section{REFERENCE}

FURMAN SELZ, 1998. The Ag Biotech and Seed Industry: The Ag Biotech and Seed Industry: The Biotech Revolution is Here. New York, NY. 744p.

Recebido para publicação em 30.07 .98 Aceito para publicação em 03.08 .98 